\title{
Is growth of eelgrass nitrogen limited? A numerical simulation of the effects of light and nitrogen on the growth dynamics of Zostera marina
}

\author{
Richard C. Zimmerman*, Robert D. Smith, Randall S. Alberte \\ Department of Molecular Genetics and Cell Biology, The University of Chicago, Chicago, Illinois 60637, USA \\ and \\ Hopkins Marine Station, Pacific Grove, California 93950, USA
}

\begin{abstract}
A numerical model of nitrogen uptake and growth was developed for the temperate seagrass Zostera marina L. Goals were to evaluate the relative effects of light and nitrogen availability on nitrogen uptake and partitioning between leaf and root tissue, and to estimate nitrogen concentrations in the sediment and water column required to saturate growth. Steady-state predictions are quite robust with respect to a range of parameter values justified by available data. The calculations indicated that roots are probably more important in overall nitrogen acquisition in most light and nitrogen environments encountered in situ, but may contribute less than $50 \%$ of the total uptake in low light. The model also predicted ammonium to be a much more important source of nitrogen than nitrate Nitrogen concentrations required to saturate growth (even for nitrate) were estimated to be at least $50 \%$ below concentrations commonly reported in situ, an indication that nitrogen limitation of $Z$. marina is probably very rare in nature.
\end{abstract}

\section{INTRODUCTION}

The temperate seagrass Zostera marina $\mathrm{L}$. is an important primary producer in coastal marine and estuarine ecosystems. As such, factors which may control its productivity in situ have received considerable attention. Because Z. marina often grows in environments characterized by turbid water columns with high coefficients of light attenuation, irradiance plays an important role in regulating the growth and spatial distribution of this macrophyte (Clough \& Attiwill 1980 Dennison \& Alberte 1982, 1986, Bulthius 1983, Wetzel \& Penhale 1983, Smith et al. 1984, Mazzella \& Alberte 1986). To support healthy growth, irradiance levels must exceed photosynthetic saturation for 6 h each day (Dennison \& Alberte 1986).

As with light, nutrient availability may also play a significant role in limiting production. Although in general photosynthetic rates are well defined for Zostera marina, our understanding of the dynamics of nutrient

\footnotetext{
- Addressee for correspondence and reprints (Hopkins Marine Station)
}

utilization is much less complete. Evidence of nutrient limitation has been reported for some eelgrass beds (Orth 1977, Harlin \& Thorne-Miller 1981, lizumi et al. 1982, Short 1983a, 1983b, 1987), yet the generality of nutrient limitation cannot always be demonstrated (Dennison et al. 1987, Pregnall et al. 1987). Furthermore, a general predictive model of nutrient-limited growth has not been developed, despite the fact that studies of nitrogen limitation have been conducted in eelgrass beds with ammonium concentrations in the sediments ranging from 50 to $500 \mu \mathrm{M}$ (lizumi et al. 1980, 1982, Short 1983a, 1983b, Dennison et al. 1987).

High ammonium concentrations within the sediments lead to significant diffusion into the water column (Short 1983b) where high concentrations of nitrate are frequently present. Although both roots and leaves of Zostera marina are capable of taking up roughly equal amounts of nitrogen under in situ conditions (Iizumi \& Hattori 1982, Short \& McRoy 1984), the importance of dissolved inorganic nitrogen concentrations in the water column has not been evaluated in any detail for this system.

To complicate the effect of nutrient availability on 
uptake dynamics, there is also a significant effect of light. Although the sediment rhizosphere is always anoxic, roots respire aerobically only during daylight hours when oxygen produced by leaf photosynthesis is transported to them (lizumi et al. 1980, Smith et al. 1984). Lack of photosynthesis at night forces roots to undergo fermentation for prolonged periods, during which time they are unable to assimilate nitrogen available in the sediments (Morris 1984, Morris \& Dacey 1984, Pregnall et al. 1987).

While mass-balance calculations based on experiments and field observations have been used to estimate nitrogen demand under specific conditions (Iizumi et al. 1982, Dennison et al. 1987, Pregnall et al. 1987), generalization of these results to a wide variety of environmental conditions is difficult. To evaluate dynamics of nitrogen utilization by Zostera marina in a more general context, we developed a mathematical model to examine the effects of light and nitrogen availability on the dynamics of nitrogen uptake and growth. The goals of this analysis were to predict partitioning of nitrogen uptake by roots and leaves under different light and nitrogen environments and to determine nitrogen concentrations required to saturate growth under different light regimes. This model represents the first attempt to provide a general theoretical analysis of the combined effects of light and nitrogen on the growth of $Z$. marina in a wide variety of habitats.

\section{THE MODEL}

The model is diagrammed schematically (Fig. 1) using the energy circuit symbolism of Odum (1983). Circular symbols represent inorganic nutrient pools and light, indicating non-depletable resources. Exter- nal inorganic nitrogen concentrations remained constant throughout each run. The large bullet-shaped symbol represents Zostera marina leaves and the partial hexagon buried in the sediment represents the root/rhizome system. The small tank symbol (labeled Q) represents nitrogen quota, or content, of the tissues. The pointed boxes (or chevrons) represent work gates, identifying interactions between the connected flows and/or compartments. Potential uptake rates $\left(V_{p}\right)$ of nitrate and ammonium for both leaves and root/ rhizome were modeled as Monod functions:

$$
V_{p}=V_{m}\left[\frac{N}{K_{s}+\bar{N}}\right]
$$

where $\mathrm{V}_{\mathrm{m}}$ and $\mathrm{K}_{\mathrm{s}}=$ theoretical maximum uptake rate and half-saturation constant, respectively, for each nutrient $_{i} N=$ nutrient concentration. Parameter values for ammonium uptake kinetics (Table 1) were obtained from Thursby \& Harlin (1982). Similar experimental data for nitrate uptake by $Z$. marina were not available, so parameters for nitrate were assumed to be the same as for ammonium. While many phytoplankton and marine macrophytes show some preference for ammonium, such differences are not great (Eppley et al. 1969, MacIssac \& Dugdale 1969, D'Elia \& DeBoer 1978, Haines \& Wheeler 1978, Hanisak \& Harlin 1978).

The potential uptake rate of each nitrogen source $\left(V_{p}\right)$ was inhibited by the size of the internal nitrogen quota $(Q)$ relative to its upper and lower limits $\left(Q_{m}\right.$ and $Q_{0}$, respectively)

$$
V_{q}=V_{p}\left[1-\frac{Q-Q_{0}}{Q_{m}-Q_{0}}\right]
$$

This formulation is similar to that proposed by Droop (1973) to describe the effects of cell nutrient quota on growth of phytoplankton. Uptake of ammonium by

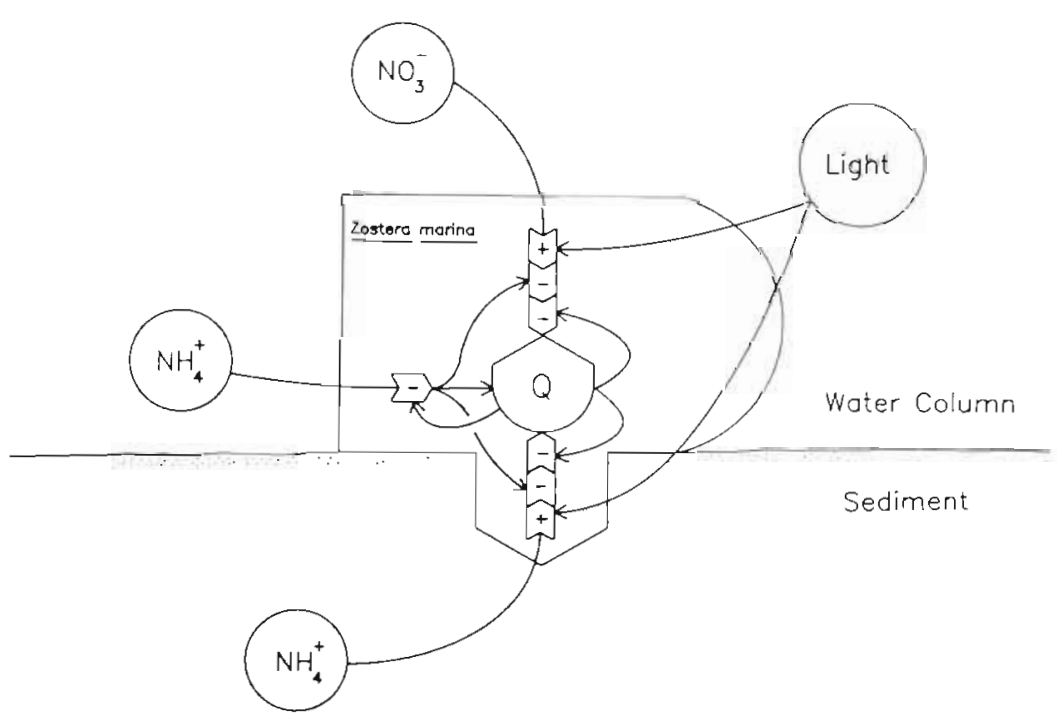

Fig. 1. Conceptual diagram of the model using the energy circuit language of Odum (1983). Nutrients and light (circles) were modeled as donor-controlled non-depletable resources. The bullet-shaped figure with the partial hexagon buried in the sediment represents Zostera marina. The small storage tank (labeled $Q$ ) represents internal nitrogen reserves. Interactions between compartments are indicated by work gates (pointed boxes). $+1-$ symbols within the work gates indicate positive and regatıve interactions 
Table 1. List of physiological constants used in the model, and their sources. $V_{m}$ : theoretical maximum uptake rate; $K_{s}$ : halfsaturation constant

\begin{tabular}{|c|c|c|}
\hline Constant & Value & Source \\
\hline $\mathrm{V}_{\mathrm{m}}$ for $\mathrm{NH}_{4}{ }^{+}$by leaves & $20.5 \mu \mathrm{Mg} \mathrm{gdry} \mathrm{wt}^{-1} \mathrm{~h}^{-1}$ & Thursby \& Harlin 1982 \\
\hline $\mathrm{K}_{\mathrm{s}}$ for $\mathrm{NH}_{4}+$ by leaves & $9.2 \mu \mathrm{M} \mathrm{NH}_{4}^{+}$ & Thursby \& Harlin 1982 \\
\hline $\mathrm{V}_{\mathrm{m}}$ for $\mathrm{NO}_{3}$ & $20.5 \mu \mathrm{Mg}$ dry $w_{t}^{-1} \mathrm{~h}^{-1}$ & Assumed same as $\mathrm{V}_{\mathrm{m}}$ for $\mathrm{NH}_{4}^{+}$by leaves \\
\hline $\mathrm{K}$, for $\mathrm{NO}_{3}{ }^{-}$ & $9.2 \mu \mathrm{M} \mathrm{NO}_{3}^{-}$ & Assumed same as $\mathrm{V}_{\mathrm{m}}$ for $\mathrm{NH}_{4}^{+}$by leaves \\
\hline $\mathrm{V}_{\mathrm{m}}$ for $\mathrm{NH}_{4}$ by roots & $211 \mu \mathrm{Mg}$ dry $\mathrm{wt}^{-1} \mathrm{~h}^{-1}$ & Thursby \& Harlin 1982 \\
\hline $\mathrm{K}_{\mathrm{s}}$ for $\mathrm{NH}_{4}^{+}$by roots & $104 \mu \mathrm{M} \mathrm{NO}_{3}^{-}$ & Thursby \& Harlin 1982 \\
\hline$Q_{\mathrm{m}}$ (maximum $\mathrm{N}$ content) & $2 \%$ of dry wt. & $\begin{array}{l}\text { Pregnall et al. } 1987 \\
\text { Short } 1987\end{array}$ \\
\hline$Q_{\circ}$ (minimum $N$ content) & $\begin{array}{l}0.95 \% \text { of dry wt (assuming } 1 \% \\
\text { for leaf and } 0.75 \% \text { for root/rhizome) }\end{array}$ & $\begin{array}{l}\text { Pregnall et al. } 1987 \\
\text { Short } 1987\end{array}$ \\
\hline Max spec. growth, $\mu$ & $0.03 \mathrm{~d}^{-1}$ & $\begin{array}{l}\text { Dennison \& Alberte } 1982 \\
\text { Short } 1987\end{array}$ \\
\hline Root: shoot biomass ratio & 0.20 & $\begin{array}{l}\text { Pregnall et al. } 1987 \\
\text { Zimmermann et al. unpubl. }\end{array}$ \\
\hline
\end{tabular}

roots and nitrate by leaves was feedback-inhibited by the degree to which ammonium uptake by the leaves was saturated:

$$
\mathrm{V}_{\mathrm{n}}=\mathrm{V}_{\mathrm{q}}\left[1-\frac{\mathrm{V}_{\mathrm{q} \text { (leaf })}}{\mathrm{V}_{\mathrm{m}(\text { leaf })}}\right]
$$

where $V_{\mathrm{q}(\text { leaf) }}$ (calculated from Eq. 2) and $V_{\text {m(leaf) }}$ (constant; Table 1) represent the realized and theoretical maximum ammonium uptake rates, respectively, of the leaves. This relation was based on the observation that exposure of Zostera marina leaves to uptake-saturating ammonium levels severely inhibited ammonium uptake by roots (Thursby \& Harlin 1982). Uptake of nitrate frequently shows inhibition by ammonium as well, presumably because ammonium inhibits nitrate reductase (Blasco \& Conway 1982).

Assimilation of ammonium from the sediment pool by the roots requires aerobic root metabolism (Morris 1984, Morris \& Dacey 1984, Pregnall et al. 1984, 1987) and was therefore modeled as an irradiance- (i.e. photosynthesis-) dependent process. Uptake of nitrate by leaves was also dependent on irradiance, as complete assimilation requires reducing power generated by light-dependent electron transport in the chloroplast to reduce nitrite to ammonium (Beevers \& Hageman 1980). The effect of photosynthesis on realized rates of nitrate uptake $\left(\mathrm{V}_{\mathrm{r}}\right)$ by leaves and ammonium uptake by roots was modeled as a linear function of photosynthesis $(\mathrm{P})$ :

$$
\mathrm{V}_{\mathrm{r}}=\mathrm{V}_{\mathrm{n}} \mathrm{P}
$$

Photosynthesis, normalized to the maximum photosynthetic rate, $\mathrm{P}_{\mathrm{m}}$, was calculated at each time step:

$$
\mathrm{P}=1-\exp (-\mathrm{I})
$$

where $\mathrm{I}=$ instantaneous irradiance, normalized to the irradiance required to saturate photosynthesis $\left(I_{k}\right)$. This formulation is simple, yet provides an excellent fit to a wide variety of photosynthesis-irradiance data (Peterson et al. 1987, Zimmerman et al. 1987).

Coefficients were scaled as listed in Table 1. Instantaneous irradiance ( $l$, normalized to $I_{k}$ ) was calculated as a function of photoperiod (D), time of day ( $T$ ), and maximum irradiance at noon $\left(\mathrm{I}_{\mathrm{m}}\right.$, again normalized to $\left.I_{k}\right)$ :

$$
I=I_{m} \sin \left(\pi \frac{T}{D}\right)
$$

Sunrise was defined as $\mathrm{T}=0$ and sunset as $\mathrm{T}=\mathrm{D}$. Irradiance (I) was set to 0 whenever $\mathrm{T}$ exceeded $\mathrm{D}$. Time (T) was reset to 0 every $24 \mathrm{~h}$. Because instantaneous irradiance was modeled as a perfect sine function, the daily period of irradiance-saturated photosynthesis $\left(\mathrm{H}_{\mathrm{sat}}\right)$ can be calculated once $\mathrm{D}$ and $\mathrm{I}_{\mathrm{m}}$ are defined:

$$
\mathrm{H}_{\text {sat }}=\mathrm{D}\left[1-\frac{2}{\pi}\left(\arcsin \mathrm{I}_{\mathrm{m}}{ }^{-1}\right)\right]
$$

Growth occurred at each time step, providing there was nitrogen in the plant available for growth (i.e. $Q>Q_{0}$ ). The specific growth rate $(\mu)$ was never allowed to be greater than $0.03 \mathrm{~d}^{-1}$, regardless of the value of $Q$. This appears to be a reasonable upper limit, considering growth rates reported from field studies (Dennison \& Alberte 1982), in mesocosm experiments (Short 1987) and estimates of annual system productivity (Mann 1982). Nitrogen content of new tissue was set to $1.00 \%$ dry wt. for leaves and $0.75 \%$ for root/rhizome (Short \& McRoy 1984, Pregnall et al. 1987, Short 1987). Growth was not permitted if the internal nitrogen quota (Q) fell below $0.95 \%$ dry wt for the whole plant (root and shoot combined). This was also the initial condition at the start of each run $\left(Q=Q_{0}\right)$. Growth was distributed between root/rhizome and shoots to maintain a constant root: shoot biomass ratio of 0.20 , which is fairly 
typical for Zostera marina in summer (Dennison \& Alberte 1987). The defined environmental conditions for the 'standard run' are listed in Table 2. All calculations were performed using a simulated time step of $1 / 64 \mathrm{~h}$ to minimize rounding errors, and each run terminated when biomass-normalized pool size, growth

Table 2. Standard run conditions

\begin{tabular}{|c|c|c|}
\hline Variable & Value & Comments \\
\hline Water column $\left[\mathrm{NO}_{3}{ }^{-}\right]$ & $5 \mu \mathrm{M}$ & Equals $0.54 \mathrm{~K}_{\mathrm{s}}$ \\
\hline Water column $\left[\mathrm{NH}_{4}{ }^{+}\right]$ & $5 \mu \mathrm{M}$ & Equals $0.54 \mathrm{~K}_{\mathrm{s}}$ \\
\hline Sediment $\left[\mathrm{NH}_{4}{ }^{+}\right]$ & $100 \mu \mathrm{M}$ & Equals $0.96 \mathrm{~K}_{5}$ \\
\hline Photoperiod, D & $12 \mathrm{~h}$ & \\
\hline Max noon irr., $I_{m}$ & $\begin{array}{l}5.56 I_{k} \\
\text { units }\end{array}$ & $\begin{array}{l}\text { Equals } 400 \mu \mathrm{E} \mathrm{m}^{-2} \mathrm{~s}^{-1} \\
\text { for } \mathrm{I}_{\mathrm{k}}=72 \mu \mathrm{E} \mathrm{m}^{-2} \mathrm{~s}^{-1}\end{array}$ \\
\hline
\end{tabular}

rate, and uptake rate had stabilized ( 7 to 10 simulated days, depending on conditions). All results presented are therefore steady-state solutions of the model for the indicated environmental and initial conditions. At steady-state, nitrogen uptake (ion transport) and assimilation (reduction and incorporation into organic compounds) must be equivalent quantitatively, even though they are distinct physiological processes. Thus, for the purposes of this model, uptake and assimilation were treated mathematically as identical processes.

\section{RESULTS}

\section{Effect of irradiance on nitrogen uptake and assimilation patterns}

Instantaneous irradiance during daylight hours was altered for different runs by adjusting the maximum noon irradiance $\left(I_{m}\right)$ and the photoperiod (D, see Eq. 6). Because the effect of $\mathrm{I}_{\mathrm{m}}$ on the period of light-saturated photosynthesis is non-linear, $I_{m}$ had its greatest effect on $\mathrm{H}_{\text {sat }}$ at values less than $3 \mathrm{I}_{\mathrm{k}}$ units (Fig. 2). There was virtually no effect of $I_{m}$ at values greater than $3 I_{k}$ units. In contrast, the effect of photoperiod (D) on $\mathrm{H}_{\text {sat }}$ was linear, as indicated by the evenly spaced isopleths of constant $\mathrm{H}_{\text {sat }}$ across the photoperiod gradient (Fig. 2).

Accordingly, $I_{m}$ had its greatest impact on patterns of nitrate uptake by leaves and roots in low-light environments (defined as $I_{m}<3 I_{k}$ units). In examining the effect of $I_{m}$ on nitrogen utilization, all other environmental variables were held constant (Table 2). Leaves took up most of the nitrogen as ammonium when maximum noon irradiance was less than $1.4 \mathrm{I}_{\mathrm{k}}$ units. Roots took up most of the nitrogen as ammonium only when $I_{m}$ exceeded $1.4 I_{k}$ units (Fig. 3). Regardless of $I_{m}$, nitrate never constituted more than $10 \%$ of total leaf

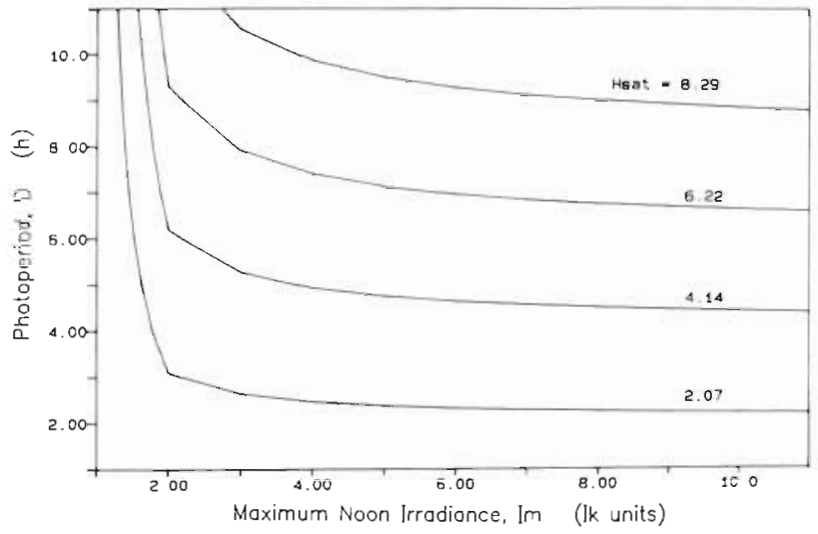

Fig. 2. Isopleths of constant $\mathrm{H}_{\text {sat }}$ plotted in parameter space defined by maximum noon irradiance $\left(I_{m}\right)$ and photoperiod (D). The effect of $I_{m}$ is greatest below $3 I_{k}$ units, with virtually no effect for $I_{m}>3 I_{k}$. In contrast, the influence of $D$ on $H_{s a t}$ was linear, as indicated by the even spacing of isopleths across the photoperiod gradient. Typical values of $I_{k}$ for Zostera marina are 70 to $100 \mu \mathrm{E} \mathrm{m}^{-2} \mathrm{~s}^{-1}$

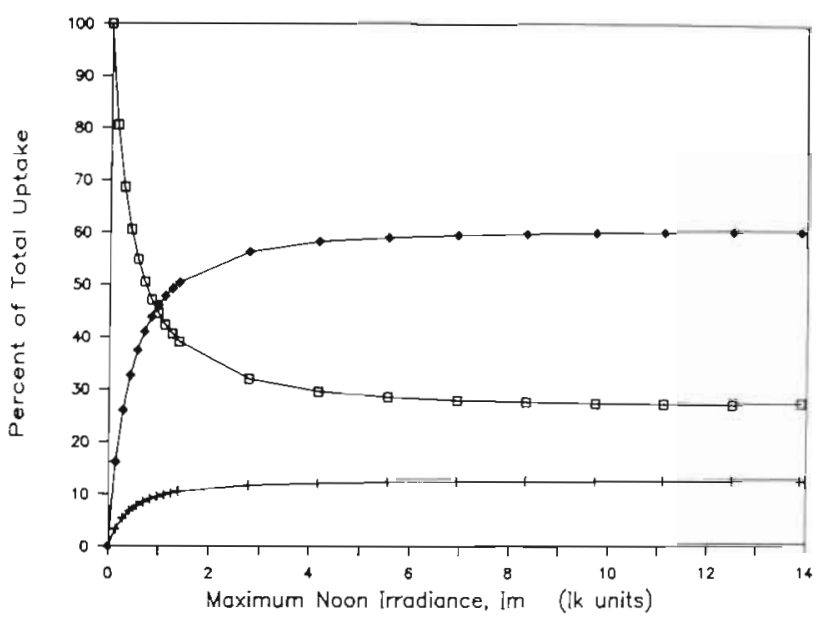

Fig. 3. Effect of maximum noon irradiance $\left(\mathrm{I}_{\mathrm{m}}\right)$ on patterns of nutrient uptake. Scale of irradiance values along the ordinate are normalized to $\mathrm{I}_{\mathrm{k}}$. Uptake by each component is plotted as a percentage of total nitrogen taken up each day. Values for all variables except $\mathrm{I}_{\mathrm{m}}$ are listed in Table 2. () Uptake of $\mathrm{NH}_{4}{ }^{+}$by leaves; (+) uptake of $\mathrm{NO}_{3}{ }^{-}$by leaves; $(\uparrow)$ uptake of $\mathrm{NH}_{4}^{+}$by roots

nitrogen uptake, and the root/rhizome system never accounted for more than $60 \%$ of the total nitrogen. Thus even when high irradiance made conditions extremely favorable for uptake of ammonium by roots, leaves still played a significant role in nitrogen uptake, providing as much as $40 \%$ of the total nitrogen each day.

Photoperiod (D) affected nitrogen uptake patterns in a similar manner. Under high light ( $I_{m}>3 I_{k}$ units), roots required a photoperiod in excess of $6 \mathrm{~h}$ to assimilate $50 \%$ of the total nitrogen (Fig. 4). Although roots 


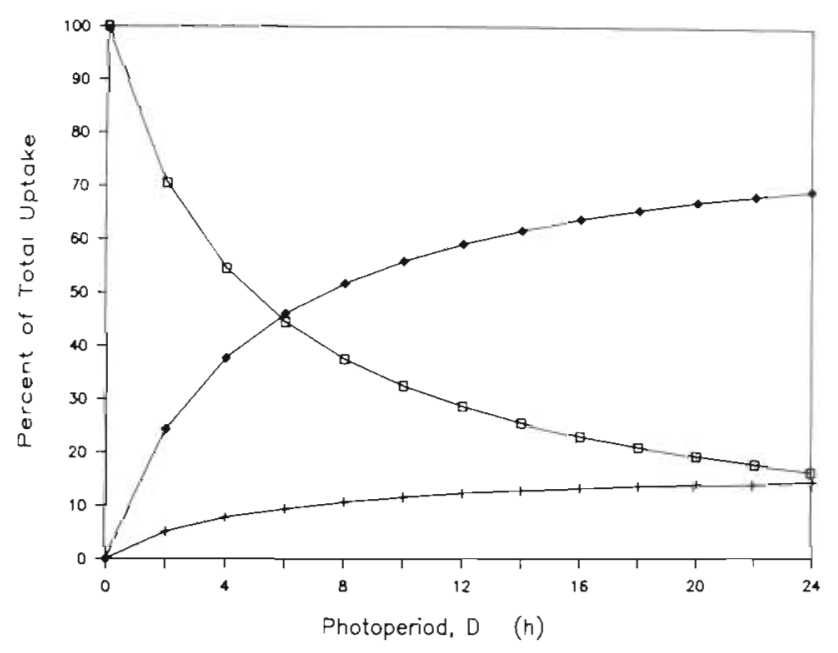

Fig. 4. Effect of day length on nutrient uptake patterns. Uptake by each component is plotted as a percentage of total nitrogen taken up each day. Values for all variables (except $D$ ) are listed in Table 2. () Uptake of $\mathrm{NH}_{4}{ }^{+}$by leaves; (+) uptake of $\mathrm{NO}_{3}{ }^{-}$by leaves; $(\bullet)$ uptake of $\mathrm{NH}_{4}{ }^{+}$by roots

took up most of the nitrogen under adequate light conditions, they never acquired more than $70 \%$ of the total nitrogen, even when $\mathrm{D}$ was $24 \mathrm{~h}\left(\mathrm{H}_{\text {sat }}=21.23 \mathrm{~h}\right)$. For more realistic photoperiods of 12 and $6 \mathrm{~h}\left(\mathrm{H}_{\text {sat }}=\right.$ 10.62 and $5.31 \mathrm{~h}$, respectively), nitrogen uptake by roots accounted for 60 and $46 \%$, respectively, of the total nitrogen.

The light environments required for roots to take up $50 \%$ of the total nitrogen, when plotted in parameter space defined by maximum noon irradiance $\left(\mathrm{I}_{\mathrm{m}}\right)$ and photoperiod (D), falls along an isopleth of constant $\mathrm{H}_{\text {sat }}$ (calculated from Eq. 8) equal to 5.9 h (Fig. 5). Combina-

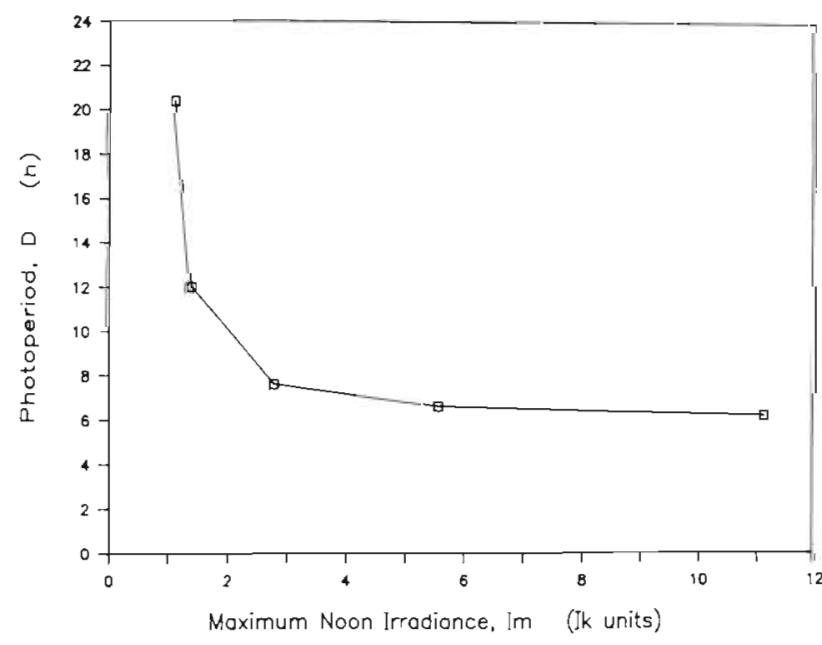

Fig. 5. The parameter space of light environments defined by photoperiod (D) and maximum noon irradiance $\left(I_{m}\right)$. The irradiance scale along the ordinate is normalized to $I_{k}$. The isopleth of equal nitrogen uptake by leaves and roots plotted in this parameter space corresponds to a constant $\mathrm{H}_{\text {sat }}$ of $5.9 \mathrm{~h}$ tions of $\mathrm{I}_{\mathrm{m}}$ and $\mathrm{D}$ resulting in $\mathrm{H}_{\text {sat }}$ periods greater than $5.9 \mathrm{~h}$ resulted in conditions where the roots took up most of the nitrogen. When $\mathrm{H}_{\text {sat }}$ was less than $5.9 \mathrm{~h}$, most of the nitrogen was taken up by leaves.

\section{Effects of sediment and water column nitrogen availability on uptake patterns}

Under standard conditions (Table 2), leaves took up $50 \%$ or more of the total nitrogen (as ammonium and nitrate) when water column ammonium concentrations exceeded $8.8 \mu \mathrm{M}$, or $95 \%$ of $\mathrm{K}_{\mathrm{s}}$ (Fig. 6). When water

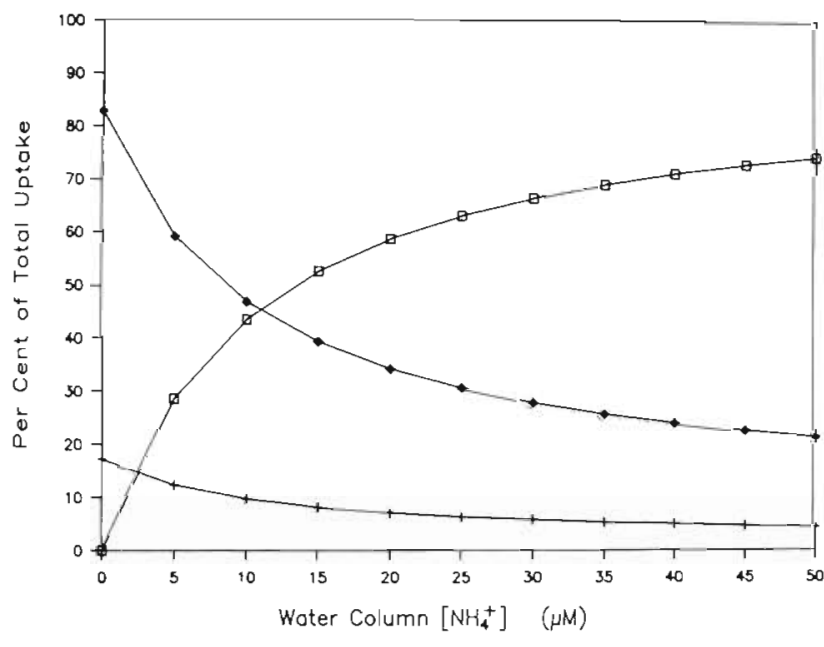

Fig. 6. Effect of water column ammonium concentrations on patterns of nitrogen uptake. Uptake by each component is plotted as a percentage of total nitrogen taken up each day. Values for all variables (except D) are listed in Table 2. (口) Uptake of $\mathrm{NH}_{4}{ }^{+}$by leaves; (+) uptake of $\mathrm{NO}_{3}{ }^{-}$by leaves; $(\bullet)$ uptake of $\mathrm{NH}_{4}{ }^{+}$by roots

column ammonium was greater than $15 \mu \mathrm{M}$, leaves assimilated as much as $75 \%$ of the total nitrogen as ammonium. As water column ammonium concentrations increased beyond $15 \mu \mathrm{M}$, uptake of nitrate by the leaves dropped asymptotically to $4 \%$, and contributions of total $\mathrm{N}$ (as ammonium) by the roots dropped to $21 \%$ (Fig. 6).

The combined effects of $\mathrm{H}_{\text {sat }}$ and water column ammonium are illustrated in Fig. 7. As in Fig. 5, the curve represents the isopleth where leaves and roots took up equal amounts of nitrogen. Combinations of $\mathrm{H}_{\text {sat }}$ and water column ammonium concentration above the isopleth represent situations (low light, high ammonium) where leaves assimilated most of the nitrogen. The area beneath the isopleth (high light, low ammonium), represents conditions under which the root/rhizome assimilated most of the nitrogen.

Ammonium concentrations in the sediment compartment also affected relative uptake rates between roots 


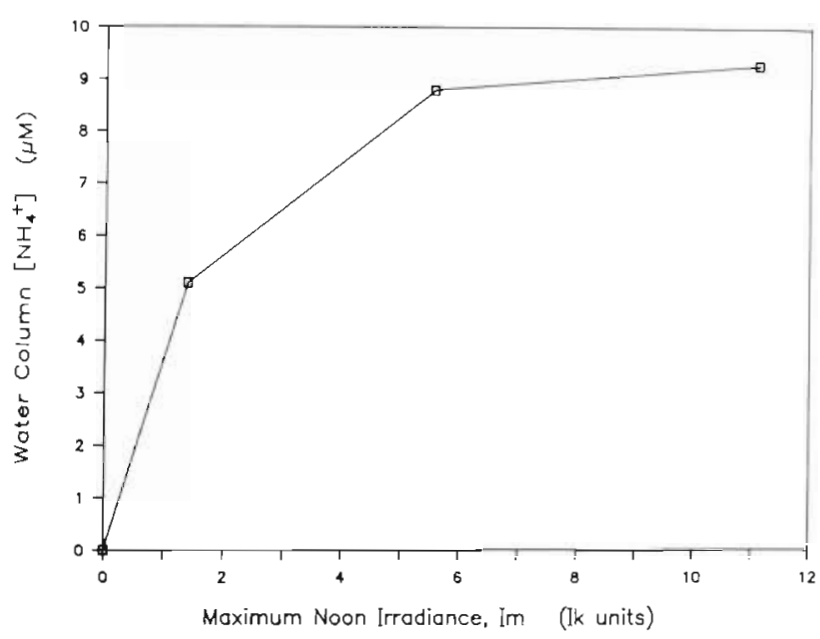

Fig. 7. Isopleth of equal nitrogen uptake by roots and leaves plotted in parameter space defined by water column ammonium concentrations and maximum noon irradiance $\left(\mathrm{I}_{\mathrm{m}}\right)$. Above the line, uptake is dominated by leaf processes. Nitrogen assimilation by roots is greater than leaves in environments characterized by high light and low water column ammonium concentrations

and leaves. Roots did not assimilate $50 \%$ of the total nitrogen until ammonium levels in the sediment exceeded $68 \mu \mathrm{M}$, or $65 \%$ of root $K_{\mathrm{s}}$ (Fig. 8). However, even when sediment ammonium concentrations were as high as $500 \mu \mathrm{M}$, leaves still assimilated $20 \%$ of the nitrogen (ammonium + nitrate). As before, nitrate represented a minor component of the total nitrogen taken up, even though nitrate and ammonium concentrations in the water column were equal.

When contoured in parameter space defined by $\mathrm{H}_{\text {sat }}$

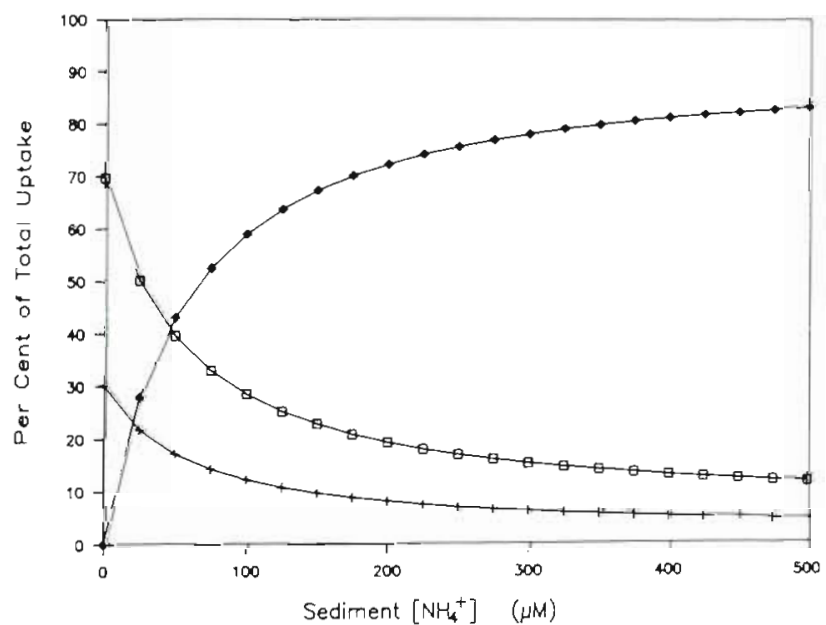

Fig. 8. Effect of sediment ammonlum concentrations on patterns of nutrogen assimilation. Uptake by each component is plotted as a percentage of total nitrogen taken up each day. Values for all variables (except D) are listed in Table 2. (E) Uptake of $\mathrm{NH}_{4}{ }^{+}$by leaves; (+) uptake of $\mathrm{NO}_{3}{ }^{-}$by leaves; $(\bullet)$ uptake of $\mathrm{NH}_{4}^{+}$by roots and sediment ammonium concentration, the isopleth of equal uptake separates those environmental conditions where roots and leaves were of prime importance in nitrogen assimilation (Fig. 9). The region above the isopleth characterizes environments under which roots

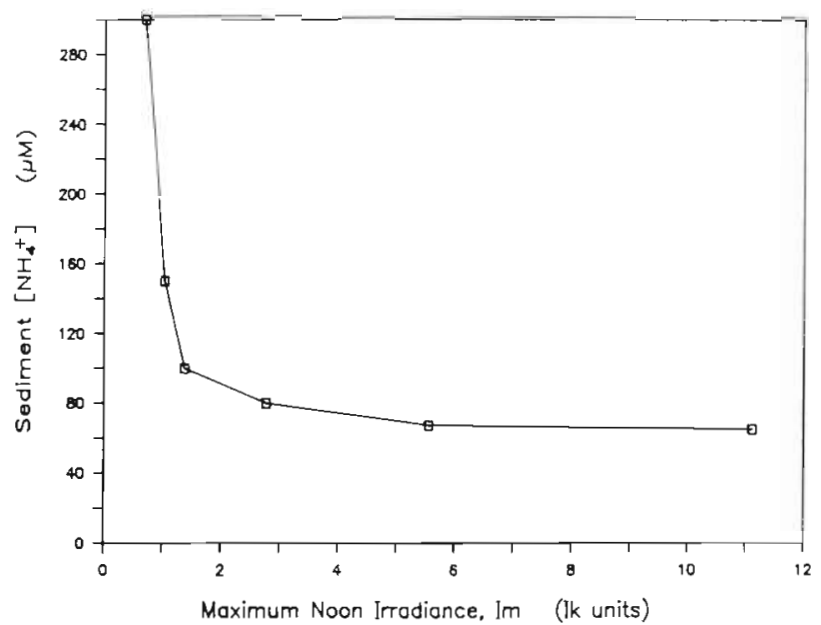

Fig. 9. Isopleth of equal nitrogen uptake by roots and leaves plotted in parameter space defined by sediment ammonium concentration and maximum noon irradiance $\left(I_{m}\right)$. Most nitrogen was assimilated by roots in environments characterized by high light and high sediment ammonium concentrations

assimilated most of the total nitrogen acquired by the plant.

Nitrate was not a primary source of nitrogen. Over the range of nitrate concentrations typically found in coastal surface waters ( 0 to $10 \mu \mathrm{M}$; Zentara \& Kamykowski 1977), nitrate represented no more than $20 \%$ of the total nitrogen utilized (Fig. 10). Even at concen-

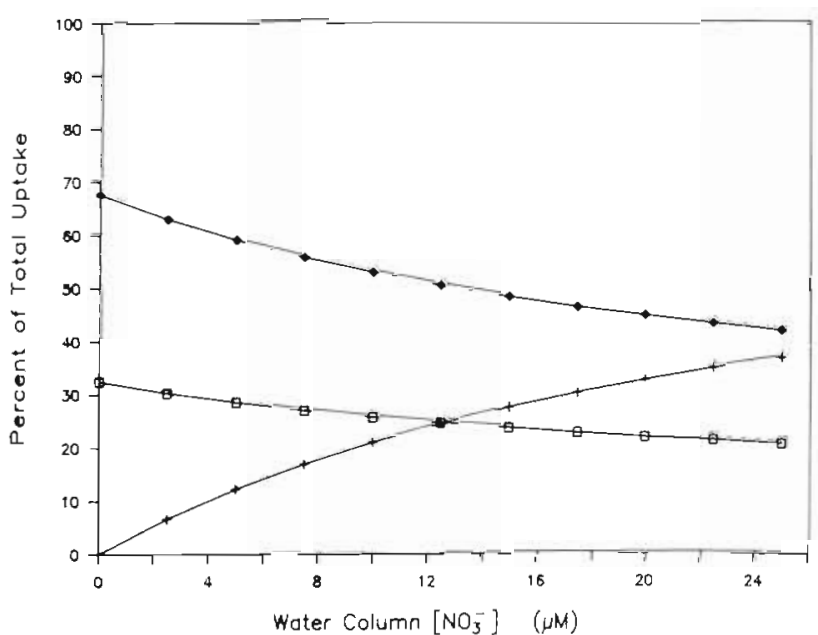

Fig. 10. Effect of water column nitrate concentrations on patterns of nitrogen uptake. Uptake by each component is plotted as a percentage of total nitrogen taken up each day. Values for all variables (except D) are listed in Table 2. ( $)$ Uptake of $\mathrm{NH}_{4}{ }^{-}$by leaves; $(+)$uptake of $\mathrm{NO}_{3}^{-}$by leaves; $(\uparrow)$ uptake of $\mathrm{NH}_{4}^{+}$by roots 
trations high enough to saturate uptake rates, nitrate accounted for no more than $40 \%$ of the total nitrogen assimilated.

\section{Effects of light and nitrogen on growth}

The $H_{\text {sat }}$ period had a significant effect on nitrogen uptake/assimilation patterns required to maintain maximum growth rates. Water column nitrate and sediment ammonium concentrations required to saturate growth decreased dramatically as $I_{m}$ increased to $1 l_{k}$ unit (Fig. $11 \& 12$ ). The effect of irradiance was greatly reduced when $I_{m}$ was greater than $I_{k}$. Water column ammonium

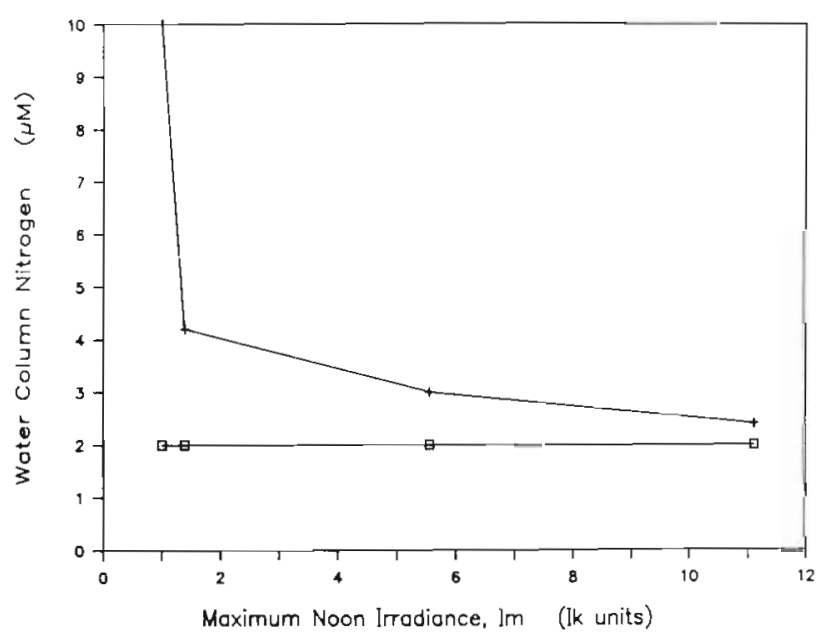

Fig. 11. Effect of maximum noon irradiance $\left(\mathrm{I}_{\mathrm{m}}\right)$ on water column ammonium ( $\square$ ) and nitrate (+) concentrations required to saturate growth rates, assuming each form is the only nitrogen source available

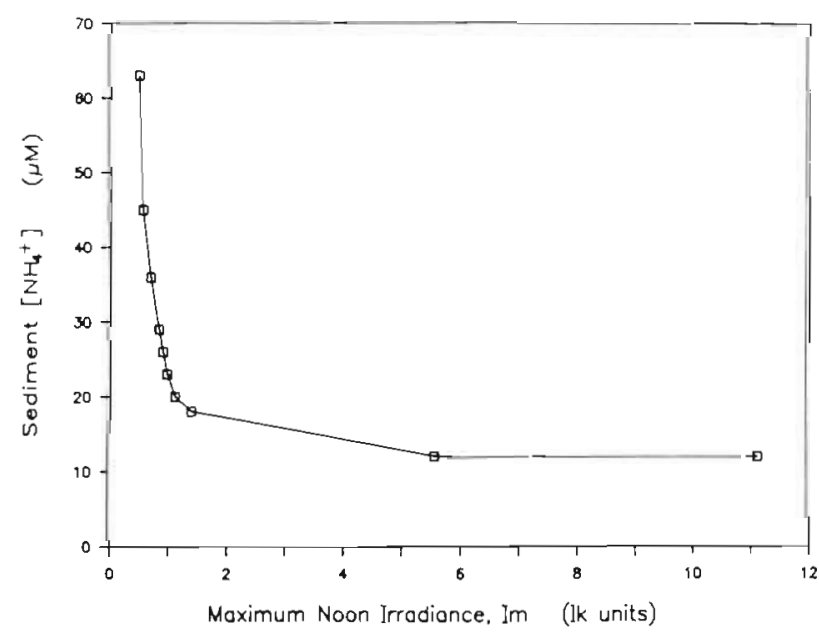

Fig. 12. Effect of maximum noon irradiance $\left(\mathrm{I}_{\mathrm{m}}\right)$ on sediment ammonium concentrations required to saturate growth, assuming no nitrogen is available in the water column concentrations required to saturate growth were independent of the light environment because there was no effect of irradiance on ammonium uptake by leaves (Fig. $2 \&$ 11).

Concentrations of nitrate and ammonium required to saturate growth were quite low relative to in situ concentrations known in Zostera marina sediments or in the water column. When other nitrogen sources were set to zero, growth saturated at a water column ammonium concentration of $2 \mu \mathrm{M}$. Nitrate concentrations in the water column required for maximum growth ranged from 3 to $4 \mu \mathrm{M}$ depending on the light environment. Sediment ammonium concentrations required to saturate growth were even more light dependent, ranging from 10 to $50 \mu \mathrm{M}$ (Fig. $11 \& 12$ ). Furthermore, if internal nitrogen reserves were full (i.e. $\left.Q=Q_{m}\right)$, growth could be maintained for at least $30 \mathrm{~d}$ in the absence of any nitrogen uptake, depending on the upper limit for $Q$ as set by $Q_{m}$.

\section{Sensitivity to parameter estimates}

Predictions of this model appear quite robust. Parameter values used in these calculations can vary by as much as $50 \%$ without affecting the steady-state results of the model by more than $5 \%$. Because uptake rates were so much higher than growth rates, the internal nitrogen pool ( $Q$ ) was almost always near its maximum values at steady-state providing nitrogen was not in limiting supply. Thus, the general predictions of this model should apply to Zostera marina populations with widely different morphologies growing in dramatically different environments.

\section{DISCUSSION}

The model presented here indicates that most of the nitrogen assimilation will occur in the roots under typical conditions found in the field $\left(\mathrm{H}_{\text {sat }}>6 \mathrm{~h}\right.$, sediment $\left[\mathrm{NH}_{4}{ }^{+}\right]=50$ to $500 \mu \mathrm{M}$, water column $\left[\mathrm{NH}_{4}{ }^{+}\right]$and $\left[\mathrm{NO}_{3}{ }^{-}\right]=1$ to $3 \mu \mathrm{M}$ each). However, the model also predicted that roots would never take up more than $70 \%$ of the total nitrogen, even with an $\mathrm{H}_{\text {sat }}$ of $24 \mathrm{~h}$. Thus, leaves probably assimilate a significant fraction of the total nitrogen, even when ammonium concentrations in the sediments are more than adequate to meet the plant's total $\mathrm{N}$ demand for growth.

While low light environments (i.e. short $\mathrm{H}_{\text {sat }}$ periods) increase the importance of nitrogen uptake/assimilation by leaves because activity of the root/rhizome system is photosynthesis-dependent (Pregnall et al. 1984, 1987. Smith et al. in press), this model predicts that leaf uptake/assimilation will account for no more 
than $60 \%$ of the total nitrogen under the shortest $\mathrm{H}_{\text {sat }}$ periods $(6 \mathrm{~h})$ where long-term survival of the plant might be expected during the summer (Dennison \& Alberte 1986). Because temperature effects on photosynthesis and respiration of Zostera marina differ (Marsh et al. 1986, Zimmerman et al. unpubl.), positive leaf carbon balances can be maintained under shorter $\mathrm{H}_{\text {sat }}$ periods at lower temperatures. Based on the model's predictions, however, even with $\mathrm{H}_{\text {sat }}$ of $4 \mathrm{~h}$, leaf nitrogen uptake/assimilation will account for no more than $60 \%$ of the total nitrogen taken up by the plant. Thus, it appears likely that leaves and root/rhizome contribute to nitrogen assimilation in roughly equal proportions under most common light and temperature environments, although the roots may dominate slightly. These predictions agree with field observations of ${ }^{15} \mathrm{~N}$ assimilation in $Z$. marina (Iizumi \& Hattori 1982, Short \& McRoy 1984).

As with light, availability of nitrogen in the water column and within the sediments are important factors regulating nitrogen uptake and assimilation by different plant tissues. Ammonium uptake by roots is strongly inhibited by the presence of ammonium in the water column surrounding the leaves (Thursby \& Harlin 1982). Since high ammonium levels within the sediments can lead to significant diffusion of ammonium into the water column (Short 1983b), ammonium uptake by the roots may be inhibited under these conditions. Typical ammonium concentrations measured within the sediments of eelgrass beds are variable, ranging at least an order of magnitude, from 50 to over $500 \mu \mathrm{M}$, depending on the particular sediment composition, rates of regeneration, uptake, diffusive loss, and other factors (Iizumi \& Hattori 1982, Short 1983a, 1983b, Boon 1986, Dennison et al. 1987). Over these concentration ranges, our model predicts relatively equal partitioning of nitrogen assimilation between leaves and roots when water column ammonium concentrations do not exceed 10 to $15 \mu \mathrm{M}$.

In addition to predicting a roughly equivalent. although slightly greater, role for roots in nitrogen uptake relative to leaves, this model predicts that growth will saturate at very low nitrogen concentrations. While $2 \mu \mathrm{M}$ ammonium concentrations may be high relative to open-ocean levels, it is clearly within the range of ammonium concentrations frequently encountered in the water column within seagrass meadows (Short 1983b, Boon 1986, Zimmerman unpubl.). Because nitrate uptake was modeled as a function of photosynthesis, water column nitrate concentrations required to saturate growth were higher than water column ammonium concentrations, and increased as $\mathrm{H}_{\text {sat }}$ decreased. Yet, relative to concentrations frequently available in temperate coastal ecosystems, nitrate requirements for growth were quite low, generally under $4 \mu \mathrm{M}$ for typical light regimes, and well within the range that one might expect to see in surface waters during at least part of the year. Sediment ammonium concentrations required to saturate growth $(10$ to $30 \mu \mathrm{M})$ were at least $50 \%$ below in situ concentrations frequently reported in the literature (50 to $500 \mu \mathrm{M}_{\mathrm{i}}$ Iizumi et al. 1982, Short 1983b, Dennison et al. 1987). Thus, based on this model, nitrogen limitation of Zostera marina in the field seems extremely unlikely.

While some experiments and mass balance calculations support this last conclusion (Dennison et al. 1987 . Pregnall et al. 1987), Zostera marina has been reported to be nutrient-limited in a number of other studies. Raymont (1947) is frequently cited as one of the earliest studies claiming that $Z$. marina was nutrient-limited. However, no data on $Z$. marina were presented; in fact the only reference to $\mathcal{Z}$. marina in the entire manuscript consists of the following statement: '. . . no fertilizers were added in summer as they encouraged at that time an extremely heavy growth of seaweed and Zostera.

Orth's (1977) field experiment provides the best evidence for nutrient limitation in Zostera marina. However, 2 commercial multinutrient fertilizers were used in this experiment $(5: 10: 10$ and $10: 10: 10 \mathrm{~N}: \mathrm{P}: \mathrm{K})$, making it impossible to determine whether growth was limited by nitrogen or phosphorus. No data on ambient nutrient availability were presented, so it is difficult to compare these results to our model.

Harlin \& Thorne-Miller (1981) performed a similar experiment, using different single-nutrient fertilizers (nitrate, ammonium and phosphate) for each treatment. Although they claimed significant effects on leaf growth in 5 of 8 treatments, our computation of the Newmann-Keuls least significant difference (LSD) for multiple comparisons (Snedecor \& Cochran 1980) based on data presented in their Table 3 indicated no significant effects of fertilization on growth, plant density or standing crop (for growth as measured by differences in leaf length, maximum difference among treatments $=23 \mathrm{~cm}, \mathrm{LSD}=25 \mathrm{~cm}$ for 1 -tail t-distribution, $\alpha=0.05)$.

Short (1983a) reported a significant positive correlation between plant morphology and sediment ammonium availability for Zostera marina growing in Izembeck Lagoon, Alaska, and he concluded that the structure of $Z$. marina beds was strongly affected by nutrient availability, despite the fact that this ammonium gradient paralleled an unquantified gradient in light availability. However, there was also a significant negative correlation between shoot density and ammonium availability. If these morphology and shoot density data are converted to standing leaf biomass using a constant coefficient of area to weight (e.g. $41 \mathrm{~cm}^{2} \mathrm{~g}^{-1}$, Zimmerman unpubl.), the biomass peak 
occurs somewhere in the middle of the ammonium gradient. If ammonium availability controlled seagrass productivity, one would expect to see biomass positively correlated with ammonium concentration.

Short (1987) examined the effect of nitrogen availability on growth and morphology of Zostera marina in laboratory mesocosms. Although there were some differences in plant morphology related to treatments effects, there was no significant difference in leaf production, leaf growth, biomass turnover rates or flower production. Ammonium concentrations in the low nutrient treatments were about $8 \mu \mathrm{M}$, which should be high enough to prevent nitrogen limitation, according to this model.

Thus, data from field studies and laboratory experiments agree with the results of our numerical model. Leaves and roots appear to be equally important in supplying the plant with nitrogen. Nitrogen limitation of eelgrass productivity in situ appears to be extremely unlikely. In addition to the model's predictions that relatively low nitrogen concentrations are required to saturate growth, these calculations indicate that Zostera marina could grow at maximum rates for at least $30 \mathrm{~d}$ in the absence of any external nitrogen inputs. In contrast, only 7 simulated days were required to completely fill the internal reserve (i.e. $Q=Q_{m}$ ). Thus, this capability for rapidly filling internal pools can buffer the plant against transient nitrogen limitation resulting from short-term changes in hydrography or rates of ammonium regeneration within the sediments.

While ammonium appears to be the most important nitrogen species for growth of eelgrass, it would be wrong to conclude that eelgrass meadows are closed systems, relying on limited biomass and/or nutrient exchange with other systems to maintain rates of nutrient regeneration required to sustain growth. In contrast, seagrass meadows are very good at trapping large quantities of particulate material, which sink to the bottom and decompose in the sediments (den Hartog 1970, Orth 1977, Harlin et al. 1982, Zieman 1982, Zimmermann \& Montgomery 1984). The fact that eelgrass communities are open systems, yet rely heavily on ammonium regeneration, is an interesting contrast to most other highly productive marine phytoplankton and macrophyte communities.

Acknowledgements. This research was supported by NSF Grant OCE 86-03369.

\section{LITERATURE CITED}

Beevers, L., Hageman, R. H. (1980). Nitrate and nitrite reduction. In: Stumph, P. K., Conn, E. E., Miflin, B. J. (ed.) The biochemistry of plants. A comprehensive treatise. 5. Academic Press, New York, p. 115-168

Blasco, D., Conway, H. L. (1982). Effect of ammonium in the regulation of nitrate assimilation in natural phytoplankton populations. J. exp. mar. Biol. Ecol. 61: 157-168

Boon, P. I. (1986). Nitrogen pools in seagrass beds of Cymodocea serrulata and Zostera capricorni of Moreton Bay, Australia. Aquat. Bot. 25: 1-19

Bulthius, D. A. (1983). Effects of in situ light reduction on density and growth of the seagrass Heterozostera tasmanica (Martens ex Aschers.) den Hartog in Western Port. Victoria, Australia. J. exp. Mar. Biol. Ecol. 67: 91-103

Clough, B. F., Attiwill, P. M. (1980). Primary productivity of Zostera muelleri Irmisch ex Aschers. in Westernport Bay (Victoria, Australia). Aquat. Bot. 9: 1-13

D'Elia, C. F., DeBoer, J. A. (1978). Nutritional studies of two red algae. II. Kinetics of ammonium and nitrate uptake. J. Phycol. 14: 266-272

den Hartog, C. (1970). The sea-grasses of the world. NorthHolland Publishing Co., Amsterdam

Dennison, W. C., Alberte, R. S. (1982). Photosynthetic response of Zostera marina L. (eelgrass) to in situ manipulations of light intensity. Oecologia (Berl.) 55: 137-144

Dennison, W. C., Alberte, R. S. (1986). Photoadaptation and growth of Zostera marina L. (eelgrass) transplants along a depth gradient. J. exp. mar. Biol. Ecol. 98: 265-282

Dennison, W. C., Aller, R. C., Alberte, R. S. (1987). Sediment ammonium availability and Zostera marina (eelgrass) growth. Mar. Biol. 94: 469-477

Droop, M. R. (1973). Some thoughts on nutrient limitation in algae. J. Phycol. 9: 264-272

Eppley, R. W., Renger, J. N., McCarthy, J. J. (1969). Halfsaturation constants for growth and nitrate uptake of marine phytoplankton. Limnol Oceanogr 14: 912-920

Haines, K. C., Wheeler, P. A. (1978). Ammonium and nitrate uptake by the marine macrophytes Hypnea musciformis (Rhodophyta) and Macrocystis pyrifera (Phaeophyta). J. Phycol. 14: 319-324

Hanisak, M. D., Harlin, M. M. (1978). Uptake of inorganic nitrogen by Codiun fragile ssp. tomentosoides (Chlorophyta). J. Phycol. 14: 450-454

Harlin, M. M., Thorne-Miller, B. (1981). Nutrient enrichment of seagrass beds in a Rhode Island coastal lagoon. Mar. Biol. 65: 221-229

Harlin, M. M., Thorne-Miller, B., Boothroyd, J. C. (1982). Seagrass-sediment dynamics of a flood-tidal delta in Rhode Island (U.S.A.). Aquat. Bot. 14: 127-138

Iizumi, H., Hattori, A. (1982). Growth and organic production of eelgrass (Zostera marina L.) in temperate waters of the Pacific coast of Japan. III. The kinetics of nitrogen uptake. Aquat. Bot. 12: 245-256

Iizumi, H., Hattori, A., McRoy, C. P. (1980). Nitrate and nitrite in interstitial waters of eelgrass beds in relation to the rhizosphere. J. exp. mar Biol. Ecol. 47: 191-201

Iizumi, H., Hattori, A., McRoy, C. P. (1982). Ammonium regeneration and assimilation in eelgrass (Zostera marina) beds. Mar. Biol. 66: 59-65

MacIsaac, J. J., Dugdale, R. C. (1969). The kinetics of nitrate and ammonia uptake by natural populations of marine phytoplankton. Deep Sea Res. 16: 45-57

Mann, K. H. (1982). Ecology of coastal waters. A systems approach. Studies in Ecology 8. University of California Press, Berkeley, California

Marsh, J. A., Dennison, W. C., Alberte, R. S. (1986). Effects of temperature on photosynthesis and respiration in eelgrass (Zostera marina L.). J. exp. mar. Biol. Ecol. 101: 257-267

Mazzella, L., Alberte, R. S. (1986). Light adaptation and the role of autotrophic epiphytes in primary production of the temperate seagrass, Zostera marina L. J. exp. mar. Biol. Ecol. 100: 165-180 
Morris, J. T (1984). Effects of oxygen and salinity on ammonium uptake by Spartina alterniflora Loisel. and Spartina patens (Aiton) Muhl. J. exp. Mar. Biol. Ecol. 78 $87-98$

Morris, J. T., Dacey, W. H. (1984). Effects of $\mathrm{O}_{2}$ on ammonium uptake and root respiration by Spartina alterniflora. Am. J. Bot. 71: 979-985

Odum, H. T. (1983). Systems ecology: an introduction. John Wiley and Sons, New York

Orth, R. J. (1977). Effect of nutrient enrichment on growth of the eelgrass Zostera marina in the Chesapeake Bay, Virginia, USA. Mar. Biol. 44: 187-194

Peterson, D. H., Perry, M. J., Bencala, K. E., Talbot, M. C. (1987). Phytoplankton productivity in relation to light intensity: a simple equation. Estuar. coast. Shelf Sci. 24: 813-832

Pregnall, A. M., Smith, R. D., Alberte, R. S. (1987). Glutamine synthetase activity and free amino acid pools of eelgrass (Zostera marina L.) roots. J. exp. mar. Biol. Ecol. 106: 211-228

Pregnall, A. M., Smith, R. D., Kursar, T A., Alberte, R. S. (1984). Metabolic adaptation of Zostera marina (eelgrass) to diurnal periods of root anoxia. Mar. Biol. 83: 141-147

Raymont, J. E. G. (1947). A fish farming experiment in Scottish sea lochs. J. mar. Res. 6: 219-227

Short, F. T (1983a). The seagrass Zostera marina L.: plant morphology and bed structure in relation to sediment ammonium in Izembeck Lagoon, Alaska. Aquat. Bot. 16: $149-161$

Short, F. T. (1983b). The response of interstitial ammonium in eelgrass (Zostera marina L.) beds to environmental perturbations. J. exp. mar. Biol. Ecol. 68: 195-208

Short, F. T (1987). Effects of sediment nutrients on seagrasses: literature review and mesocosm experiment. Aquat. Bot. 27: $41-57$

Short, F. T., McRoy, C. P. (1984). Nitrogen uptake by leaves and roots of the seagrass Zostera marina L. Botanica mar 17: $547-555$

Smith, R. D., Dennison, W C., Alberte, R. S. (1984). Role of seagrass photosynthesis in root aerobic processes. Plant Physiol. 74: 1055-1058

Smith, R. D., Pregnall, A. M., Alberte, R. S. (in press). Effects of anaerobiosis on root metabolism of the seagrass Zostera marina L. (eelgrass). Mar. Biol.

Snedecor, G. W., Cochran, W. G. (1980). Statistical methods. Iowa State University Press, Ames, Iowa

Thursby, G. B., Harlin, M. M. (1982). Leaf-root interactions in the uptake of ammonia by Zostera marina. Mar. Biol. 72: 109-112 Wetzel, R. L., Penhale, P. A. (1983). Production ecology of seagrass communities in the lower Chesapeake Bay. Mar. Tech. Soc. 17: 22-31

Zentara, S. J., Kamykowski, D. (1977). Latitudinal relationships among temperature and selected plant nutrients along the west coast of North and South America. J mar. Res. 35: 321-337

Zieman, J. C. (1982). The ecology of the seagrasses of south Florida: a community profile. U.S. Wildl Serv FWS/OBS82/25. Washington, D.C.

Zimmermann, C. F., Montgomery, J. R. (1984). Effects of a decomposing drift algal mat on sediment pore water nutrient concentrations in a Florida seagrass bed. Mar. Ecol. Prog. Ser. 19: 299-302

Zimmerman, R. C., SooHoo, J. B., Kremer, J. N., D'Argenio, D. Z. (1987). Evaluation of variance approximation techniques for non-linear photosynthesis-irradiance models. Mar. Biol. 95: 209-215 